\title{
COMMENTARY
}

\section{Entitlement and the shaping of First World War commemorative histories}

Maggie Andrews, University of Worcester

CONTACT: maggie.andrews@worc.ac.uk

The four years of commemorative outpouring and activities in response to the Centenary of the First World War have led to the production of a multiplicity of amateur and professional, academic, media and community histories of the conflict. These can be seen as exciting examples of what Raphael Samuel once optimistically described as history made by a thousand hands, which can democratize the past. However, all histories are framed by the cultural milieu in which they are produced and the centenary of the first industrialised conflict, which cost the lives of millions across the world ${ }^{1}$ is taking place in Britain, a fractured country, still reeling from the aftermath of the 2007-8 financial crisis, which heralded in austerity politics and a restructuring of welfare provision. The centenary has coincided with the rise of UKIP and 2016's divisive referendum about Britain's membership of the EU. The commemoration of a conflict, which has a significant place in British national narratives is taking place against a backdrop of hotly contested debates about who exactly is entitled to see themselves as part of the nation, and who is entitled to support from the national purse if they are in crisis. This has an inevitable, though perhaps, unintentional consequence on the selectivity and the silences in the histories of the First World War that have emerged. My own recent work with heritage organisations and community groups as part of the Arts and Humanities Research Council (AHRC) funded Voices of War and Peace World War One Engagement Centre ${ }^{2}$, suggests that in the present political climate, despite the best intentions and determined efforts of many cultural agents, some hands were much more likely to feel entitled to make histories of the First World War, than others.

Feeling entitled to construct the past, to write history, rests on both access to resources and a sense of cultural belonging. Michael Skey has pointed out that hierarchies of belonging are "linked to entitlement", in relation to immigration and has drawn attention to the: "anxieties and concerns of those who no longer feel 'at home' in what they consider to be 'their' country"(Skey, 2014, p326). Arguably 
poverty, disability, geographical location or dependency may mean that many groups do not feel they belong in austerity Britain. For, as Jon Burnett argues: "social entitlements are ever more codified and restricted, rights seen as linked to (and dependent on) responsibilities, with certain categories of persons.... excluded from some rights altogether". Cultural rights, having one's voice and experience, one's history and heritage contribute to national narratives should belong to the many not the few. Yet, producing histories relies upon both feeling able and entitled to access the resources needed to make this happen. The lion's share of resources provided to explore the history of the First World War in Britain is in the hands of large institutional players and nationally recognized cultural institutions: the $B B C$, the Imperial War Museum (IWM), Universities, the Heritage Lottery Fund and other heritage organisations. Their cultural heritage legitimates their entitlement to these funds as big players in the commemoration. But their support has often been linked to engagement with those who without a sense of entitlement. In an era where the ground on which cultural and heritage institutions operate is unstable and shifting, many have sought to reach out to the wider populace in their centenary activities.

The BBC had commissioned over 140 programmes by the middle of 2014 and that year also organized a series of community engagement roadshows, for example in Wolverhampton and Stoke-on-Trent. The AHRC allocated several million pounds to set up five Engagement Centres to support and encourage universities to work with heritage organisations and community partners. More than 30 community/academic co-produced research projects between communities and academic researchers, received up to $£ 15,000$ each. These include, for example, Refugee Tales: viewing the Belgian refugee crisis of WW1 through the lens of contemporary experience. ${ }^{3}$ Arts Council England and the HLF made a number of significant grants to museums: the IWM, London was awarded $f 6.5$ million by HLF and $f 5$ million from the Department of Culture, Media and Sport to revamp its First World War galleries ${ }^{4}$. Regional archives have also obtained significant support: Surrey was awarded $£ 460,000$ by HLF and Worcestershire Archives and Archeological Society, over one third of a million pounds to work in tandem with a number of museums across the county; their activities will culminate in a Peoples' Exhibition in 
2018. In what is, perhaps, a uniquely commendable attempt to democratize the production of knowledge about the conflict and stimulate the creation of multiple different histories, HLF set up the First World War Then and Now grant programme, which provides grants of $£ 3,000-£ 10,000$ to community groups. This initiative was so popular that extra funds were allocated to it. By March 2017, HLF had awarded over $£ 83.5$ million to more than 1,650 projects $^{5}$. Many of these have had a local focus and the scope to move beyond those who are remembered on war memorials. They include projects on women's work, stories of the factory workers in Birmingham munitions factories, army wives and women's football.

Arguably, even to apply for a small HLF grant requires a level of what Pierre Bourdieu described as "cultural capital" (1997), the upbringing, background confidence and understanding of the cultural norms and expectations, needed to navigate contemporary culture. It is not merely the education and administrative experience of certain social groups which facilitate the confidence to complete the Expression of interest form or the 16 page Application form, or the technical know how and resources to submit it online. These are not necessarily the prerogative of the retiree from middle-class professions who are the leading lights of many local history societies. But, these social groups are more likely than others to have a sense of entitlement that their village, community, ancestors have a story which deserves to be told. This sense of entitlement may be provided by a life spent occupying the spaces and places of privilege, of power, developing skills and confidence to speak for oneself and for others. But, it is also the assurance of feeling "at home", of belonging to the nation, which gives some groups a sense of effortless entitlement to play a role in constructing national narratives of the First World War. It is not just at the point of applying for a grant that this is needed. In a cultural climate of austerity there is something more complex going on, particularly in an era when the nation is far from being "all in it together". It is necessary to think quite carefully about who feels that it is appropriate to apply for an HLF, or other, grant, but also who feels justified spending money on their culture and heritage. 
Academics, professional heritage, social enterprises or community workers can support and assist groups, apply for funding, but the management and allocation of such money is problematic for those with no sense of entitlement. Expenditure that seems day-to-day to heritage workers, those working in museums, archives and universities can be seen by others as excessive and extravagant - even if they participated in the application itself. Those for who constant scrimping and saving are ways of life, or struggling to survive on benefits or the state pension, often find it unpalatable, or at least uncomfortable, if not downright wasteful to spend money on professionally produced banners for exhibitions, musicians for launch events, high quality mounting for exhibitions even commercially produced badges for children. The technical expertise needed to make websites look professional may seem absurd. Their everyday lives gives them a very different sense of the meaning of money, of the opportunity cost of expenditure on heritage in austerity Britain. And, yet, without these accouterments of heritage communication in contemporary culture, who will encounter their history, who will take it seriously in an imageconscious, style-focused media age? The possibilities of sharing histories via new media seem endless, but there is a need for a note of caution about the internet's democratizing promise. The boundless quantity of material that is produced means that almost everything is lost in the noise. The flowering of a thousand voices that Ithiel de Sola Pool (1983) hoped this new medium would produce some 30 years ago has been replaced by browsers either viewing slick professionally produced websites or their own little subgroups.

Attempts to physically bring together small community groups, for knowledge exchange, sharing or showcasing their histories are also problematic. To the cosmopolitan urban elite the physical travel required to engage in such events is passé. The technology resources and knowhow for virtual exchange via Skype and Facetime, or to upload Youtube videos is mundane, but in Britain today this is not the case for all. For example, the one in seven people who retire on the basic state pension alone ${ }^{6}$, or whose retirement involves significant caring responsibilities for a parent, partner or grandchildren, remain isolated. The significance of their research, their memories and histories is more than likely to remain hidden. 
The merging of old and new technologies through the publication of books communicated in print and kindle form with publishers such as History Press, Amberley, and Pen and Sword has sometimes delivered the work of local history groups into a national era. But, this often requires support with writing, negotiating publishing deals, a sense of entitlement and also a willingness, within a commercial environment, to shoehorn a group's history into existing national narratives of the conflict. Narratives of the First World War, which rest not merely on history books and political rhetoric, but on history lessons and war poetry read at school, novels, films, television and, of course, watching the BBC sit-com Black Adder (1989). National narratives of the past are, as Katherine Lindberg points out (1996), worn like a prosthetic limb. They are also intrinsically intertwined with a sense of belonging and entitlement within Britain. The lexicon of images from which the public imagination is stirred, and publishers' sales rely, rests upon private domestic or public memorials of military casualties. They rely on family photographs on fireplaces or in family albums, showing men in their uniform before they went off to war, or images on pintrest of propaganda material indicating how the government wanted the population to behave - not necessarily how it did. These suggest narratives of brave Tommies who fought for their country, and occasionally of Tommy's sister who worked in a munitions factory, or a wife or girlfriend who apparently sent men off to war, pointing to France and instructing them to 'GO". ${ }^{7}$

For the disposed and marginalized, participation and support of armed conflict is one route through which to gain a sense of belonging in "their country", a sense of entitlement to produce their history and have it included in national narratives of the First World War. The possibility of publishing contracts, funding and wide dissemination of histories by those not from the white middle classes all too often rests, as Sarah Lloyd, has pointed out ${ }^{8}$, on association with the military - as, for example, the HLF award to explore the contribution of Sikh soldiers to the First World War. ${ }^{9}$ Thus, the very title of the book I produced with community historians, local groups with HLF grants and students in 2016, How the Pershore Plum won the Great War, justified the place of the ordinary people's histories in the national 
narrative of the era through their contribution to "winning the war", albeit through the production, preservation and preparation of food.

As we are set to embrace the next large hopefully participatory centenary, the partial enfranchisement of women in 1918, there is a real need to consider who will feel entitled to produce histories of women's struggle for the vote and what narratives they will have to engage with to feel a sense of entitlement. and how we can democratize those who feel entitled to write their histories.

\section{Maggie Andrews}

Maggie Andrews is Professor of Cultural History at the University of Worcester. Her research and publications focus upon social and cultural history of Britain in the twentieth century and how that history is portrayed in popular culture. They include The Home Front: Images, Myths and Forgotten Experiences, (Palgrave Macmillan 2014) and The Acceptable Face of Feminism: The Women's Institute Movement 1915-1960 (Lawrence and Wishart 2015). She is the Historical Consultant to Radio 4's drama series Home Front and a Co-I on the AHRC funded Voices of War and Peace; WWI Engagement Centre http://www.voicesofwarandpeace.org.

\section{References}

Andrews, M., \& Waugh, J. (2016). How the Pershore Plum Won the Great War, History Press

Bourdieu, P. (1997). Capital cultural, escuela y espacio social. Buenos Aires: Siglo xxi editores

Burnett, J (2016). Entitlement and belonging: social restructuring and multicultural Britain, Race \& Class, 58.2, pp. 37-54.

Lindberg, K. V. (1996) Prosthetic mnemonics and prophylactic politics: William Gibson among the subjectivity mechanisms, boundary 2 23.2, pp.:47-83.

Pool, de Sola I. (1983). Technologies of freedom. Harvard University Press,

Samuel, R. (2012). Theatres of memory: Past and present in contemporary culture. Verso Books,

Skey, M. (2014). How Do You Think I Feel? It's My Country': Belonging, Entitlement and the Politics of Immigration. The Political Quarterly, 85.3, pp. 326-332, 


\section{Notes}

1 There continues to be debate about the number of casualties from the conflict, some estimates are of 20 million civilian and military deaths see http://www.centrerobert-schuman.org/userfiles/files/REPERES\%20-\%20module\%201-1-1\%20\%20explanatory\%20notes\%20-\%20World\%20War\%201\%20casualties\%20-\%20EN.pdf

2 http://www.voicesofwarandpeace.org/

3 See http://www.voicesofwarandpeace.org/voices-projects/

4 http://www.iwm.org.uk/sites/default/files/pressrelease/First\%20World\%20War\%20Galleries\%20at\%20IWM\%20London_0.pdf

5 Elise Turner, 'Heritage Lottery Fund and the First World War Centenary' presentation at the Women's History West Midlands Conference: Remembering the WWI Home Front in the Midlands. Museum of Carpet Spring 2017.

6 https://www.express.co.uk/news/uk/782041/pension-warning-retirement-savingsbritain-money-crisis

7 See the classic Women of "Britain Say Go' poster at http://www.iwm.org.uk/collections/item/object/14592

8 Professor Sarah Lloyd, Principal Investigator of the Everyday Lives in War, World War One Engagement Centre panel discussion at the Social History Conference at University of Lancaster, March 2016

9https://staticl.squarespace.com/static/52dfa66fe4b065c6bc9063bc/t/5775a727c53 4a529b307dbd7/1467328297020/2013-10-22--

Sikh+soldiers+and+the+First+World+Wart+a+history+to+be+told+_+Heritage+Lottery+Fund.pdf 